\title{
ORGANIZATIONAL DEVELOPMENT OF RUSSIAN SMEs: CURRENT TRENDS
}

\author{
Emil Velinov \\ University of Economics, Prague, Czech Republic \\ Maxim Ponomarev \\ Plekhanov Russian University of Economics, Moscow
}

\begin{abstract}
The research paper sheds a light on Russian SMEs transition and specifically on their current development and evolution. The paper attempts to explain what are the main drivers and antecedents on SMEs during the period 2010-2015. Along with it, it is applied detailed analysis of Russian SMEs in terms of key performance indicators, turnover and volume of sales. Further, are given potential developments and trends within SMEs in Russia. The paper draws attention to socio-economic and political factors influencing SMEs development.
\end{abstract}

Keywords: Transition, SMEs, Russia, current trends, developments.

DOI: http://dx.doi.org/10.15549/jeecar.v3i2.142

\section{INTRODUCTION}

\section{Purpose}

The paper attempts to explore current developments of SMEs in the Russian Federations, their antecedents on the economy and future scenarios for their evolution. Furthermore, the paper revises literature on SMEs transition.

\section{Design/methodology/approach}

Literature Review on SMEs transition and Quantitative research on Russian SMEs and specifically of their transition in the Russian economy.

\section{Findings}

There are some very light signals of the change of the economic policy in Russia towards increasing independence of the economy from the oil and gas prices on the international market, and more attention from the state to the SME sector development.

\section{Originality/value}

This paper demonstrates that the Russian SMEs are picking up speed in terms of economy growth and they are becoming major engines for exiting of the Russian economy from economic crisis

\section{LITERATURE REVIEW}

Russia is a geographic giant with rapidly growing economy and great capacities in terms of natural energy sources and investment possibilities. Promoting small and medium enterprises (SMEs) as the main generator of growth, employment and revenue diversification has become a focus of national governmental policy. The most prominent 
unitary indicator of growth has been growth in sales (Ardishvili et al. 1998; Hoy et al. 1992; Weinzimmer et al. 1998; Wiklund 1999). On the other hand, the majority of firms start as small organizations, exist as small firms and disappear as small firms. They never enter into growth trajectory (Aldrich 1999; Reynolds and White 1997; Storey 1994). In 2010 the government allocated 600 million Euros (\$777 million) in startup business incubators, micro loans, support for youth entrepreneurship, business training and 140,000 jobs were created. Still, small and medium-sized firms account for $20 \%$ of employment in Russia as of year 2015. The government aims to remove structural barriers in order to promote growth of SMEs. Russian SMEs currently represent less than $30 \%$ of the total workforce, but the government's intention is to increase it to $50 \%$ by 2020 . The national strategy for further economic development focuses on increasing competition, creating a favorable economic environment that encourages long-term investments.

Russian government tends to make the Russian Federation one of the most enticing places to do business in Eurasia and a national initiative has been created to boost investment climate for all businesses-domestic and foreign. The investor climate agenda includes rigorous policy reforms varying from tax reliefs for investors to simplifying regulation, privatization, improving procedures for public tenders and supporting innovation.

Nowadays, in the international business literature and theories, SMEs represent prevailing source of economic growth, dynamics and flexibility in the developed and developing countries. It stems from the fact that SMEs are the dominant form of business organization, representing approximately $95-99 \%$ of all enterprises. According to the Organization for Economic Cooperation and Development (OECD), SMEs represent more than 95\% of enterprises and contribute to creating $60-70 \%$ of the jobs across the Globe. The latter SMEs are presented in all sectors of the economy, and it is especially noticeable in the area of services, catering, wholesale, retail trade, consumer goods and food industries. Thus, SMEs are key players in promoting competitiveness and bringing new products or services to the market.
There is no global agreement on the definition of SMEs, but one thing virtually every country does agree on is that they are essential for economic prosperity, as SMEs make up the vast majority of businesses in most countries and employ a significant percentage of the global workforce.

Popular definitions of SME usually vary when considering employee counts, turnover or balance sheet figures. This study uses the definition for SME as presented by the European Commission (2005) which states that a small enterprise employs 10 to 49 people, has a turnover of two to 10 million euros, or has a total balance sheet ranging from two to 10 million euros. For medium sized enterprises the corresponding figures are 50 to 249 employees, turnover of over 10 million euros but less than 50 million, and a balance sheet totaling more than 10 million euros but less than 43 million. This number, however, varies across countries. In the words of the Organization for Economic Co-operation and Development (OECD) Glossary of Statistical Terms "the most frequent upper limit designating SMEs is 250 employees, as in the European Union". Some countries set the limit at 200 employees, while the United States considers SMEs to include firms with fewer than 500 employees. In most OECD countries small enterprises are those with fewer than 50 employees, while micro-enterprises have at most 10 or, in some cases, 5 employees. In addition to this, financial assets are also used to define SMEs.

It is also noteworthy, that there are several challenges that have to be met when analyzing data about the size of the SMEs across countries regarding comparability and consistency, as different nations adopt different criteria. In most of the cases, these criteria to define small and medium enterprises include employment, total net asset, sales, and investment level. It is quite difficult to analyze and compare the landscape of SMEs, as there is often the lack of existing data on SMEs and widely diverging definitions used for SME categorization. Mainly, employment is the basis for definition. As it was mentioned above, the majority of sources define SMEs to have a total of 250 employees. Basically, there are two different accrual methods, namely the qualitative and the quantitative method in order to categorize SMEs (Kayser, 2006).

The qualitative (ordinal) differentiation uses a 
catalogue of variables full of descriptive criteria that might be applicable to SMEs. The more specific criteria are fulfilled, the more obvious is the differentiation between SMEs and large concerns. According to Glancey (1998) one of those criteria is the nature of the decision-making process of a company. He argues against quantitative differentiations stressing that a firm's key factors can diverge widely between the individual industries and regions. In SMEs, control and ownership are in most of the cases in the hands of one person. In contrast, in large firms there are on the one hand usually more decision makers and on the other hand they are more likely to act in favor of the company's shareholders than for the benefit of the firm (Glancey, 1998).

SME definition in Russia was stipulated by the Federal Law of July 24, 2007 № 209-FZ “On the development of small and medium entrepreneurship in the Russian Federation" and by the Government Decree of February 9, 2013 №101 “On the thresholds of sales revenues for each SME category” (See Table 1).

\section{METHODOLOGY AND DATA COLLECTION}

The paper employs secondary (aggregated) data collected for the period 2010-2015 on Small and Medium-Sized Companies in Russian Federation. The statistical data is collected from the Russian Statistical Department. Furthermore, the research paper employs key performance indicators (KPIs) of the Russians SMEs in order to reveal the current developments and changes which have taken place since the financial crisis in 2008. Moreover, the research paper comprises of detailed characteristics on several important factors influencing SMEs development as national policy for SMEs tax ease off, policies for regional development, cross-border business activities between the Russian SMEs and foreign entities, etc. In the paper are employed descriptive statistics demonstrating the emerging trends for economic growth among the Russian SMEs as a part of their organizational development. Then in the last part of the paper it is discussed recent development of the Russian SMEs in terms of external factors as legislation amendments, governmental interventions and business competitors' development which are influencing the key performance indicators in the selected SMEs.

\section{DISCUSSIONS AND FINDINGS}

As it was noted, the European Commission has introduced the definition for SMEs in 2005, which includes staff headcount, annual turnover and balance sheet. Those criteria are not uncommonly used internationally, but with varying thresholds.

The following table summarizes the differences in definitions of medium-sized, small and micro enterprises in Russia and the European Union.

Overall, in order to count as a SME in Russia, firms do have to fulfill the following quantitative criteria regarding the number of employees and the annual turnover. In contrast to the EU there is no option to choose between turnover and the balance sheet.

Russian Law provides definitions of two categories of companies based on the dimension of the enterprise activity, the small enterprises and the large and medium enterprises. These definitions are important because they are used in officially published statistics, which are calculated in accordance with the law in ancillary normative acts such as the regulations issued by the CBR. The range of enterprises constituting small business is defined by Federal Law Nr. 88 of 14 June 1995 "On State Support to Small Business in the Russian Federation", which includes individual entrepreneurs without legal status, farmers and small enterprises legal entities. In addition, the law defines the small enterprises as enterprises being legal entities, registered with the State and having no more than 100 employees in total. In practice, of these three categories, only small enterprises have retained the attention of officials and have been subject to statistical record keeping. As a result, there has been little systematic analysis of the role played by individual entrepreneurs in the Russian economy. It is estimated that at least 40\% of Russian SMEs are in the "shadow economy", i.e. are not registered, keep no official books and pay no taxes. This is particularly true in the following industries: textile, trade of technical equipment and computer programs, alcohol and green markets. Moreover, statistics concerning small enterprises in Russia are particularly unreliable due to the following reasons:

- many enterprises encourage employees to take on the status of individual entrepreneurs in order to benefit from the simplified tax system available to small enterprises; 
- much individual entrepreneurial activity goes unregistered, potentially under-estimating the contribution of small business;

- large number of employees are part-time employed in two or more businesses but are registered only in one.

Also, a major setback of the definition of small enterprises is that it does not take into account financial criteria. As a result, a large number of enterprises active in wholesale in particular qualify as small enterprises in Russia while they would be considered otherwise in Western countries.

Also, entrepreneurs in Russia face different local practices depending on where they establish their businesses. The demand for business services is usually lower in smaller cities than in large business centers. That can lead to bottlenecks and higher costs for services in large cities, but these also benefit from economies of scale and might have more resources to invest in administrative modernization.

The initial goals of state policy in the area of development of SMEs in Russia are as follows:

- developing small and medium businesses with the purpose of creating a competitive environment in the economy of Russia;

- fostering conditions favorable for the development of SMEs; rendering assistance to SMEs in the promotion of goods and services;

- growing the number of SMEs;

- multiplying the share of taxes paid by SMEs in the tax revenues of the federal budget, the budgets of the subjects of the Russian Federation and local budgets.

- The main principles of state policy in the area of development of SMEs in the Russian Federation are as follows:

- the designation of the powers of supporting SMEs among governmental bodies;

- the responsibility of governmental bodies for ensuring favorable conditions for the development of SMEs;

- the participation of representatives of small businesses, and not-for-profit organizations expressing the interests of small and medium businesses in the formation and implementation of state policy in the area of development of small and medium scale entrepreneurship, expert examination of draft normative acts of the Russian Federation, draft legal acts of subjects of the Russian Federation, draft legal acts of local self-governing bodies regulating the development of small and medium scale entrepreneurship;

- the provision of equal access for small and medium businesses to support in accordance with the terms and conditions for the provision of the established governmental programs and for the development of SMEs.

\section{Key SME sector indicators in Russia for 2015}

The total number or registered operating SMEs in Russia as of January 2015 is 4.5 million, including micro-, small, medium-sized enterprises and individual entrepreneurs. They provide jobs for over $18 \mathrm{mln}$. people, which is $25 \%$ of total employment in Russia's economy.

According to Rosstat, the core of the SME sector in Russia (94.3\%) is composed of segment of individual entrepreneurs $-2.4 \mathrm{mln}$. or $53.3 \%$ of all SMEs - and micro enterprises $-1.9 \mathrm{mln}$. or $41 \%$ of all SMEs. Small enterprises account for $5.2 \%$ of all SMEs, while medium-sized enterprises make up $0.3 \%$ of all SMEs. Micro enterprises and individual entrepreneurs account for $55 \%$ of all jobs in the SME sector.

\section{SME performance trends in 2010-2014}

In 2010-2014 the number of microenterprises steadily grew, although the growth rates in recent two years have decreased, as it is shown in Table 2. In fact, the number of micro- and small businesses has noticeably increased by $28 \%$ within 4 years, from 1644.3 thousand in 2010 to 2103.8 thousand in 2014. In 2014, the total number of micro enterprises increased almost by $1 / 3$, as compared to 2010, and attained 1868.2 thousand. However, the number of new microenterprises in 2014 was only 40 thousand, as compared to 2013 , or $2.2 \%$.

The growth in number of micro- and small enterprises in recent 5 years has been accompanied by a lowering in number of mediumsized businesses. The number of medium businesses in 2014 was the same as in 2013 or 13.7 thousand. The $1 / 2$ downsizing of the medium business segment in 2013,13.7 thousand, against 25.2 thousand in 2010 , is due to application of new 
criteria for SMEs, including sales revenues and share of private capital. The latter one is the most complicated criterion in terms of application scope. Sometimes it was applied not only to company founders -individuals, but also to the organizations which were company founders.

The five years, 2010-2014, demonstrated a noticeable $34 \%$ increase in employment at microenterprises, from $3.3 \mathrm{mln}$. people in 2010 to $4.4 \mathrm{mln}$. people in 2014. The total employment at micro- and small enterprises grew within four years by $10.2 \%$ - from $9.7 \mathrm{mln}$. people in 2010 to10.8 $\mathrm{mln}$. people in 2014. In the segment of medium business, the total employment reduced from $2.4 \mathrm{bln}$. people in 2010 down to $1.6 \mathrm{bln}$. people in 2014 , or by $35 \%$. The total sales revenues of micro- and small enterprises steadily grew within 5 years and attained 26392.2 bln. RUR. in 2014 , which is $40 \%$ higher than that in 2010 or 18933.8 bln. RUR. The total sales revenues of medium-sized enterprises decreased within 5 years from 7416.2 bln. RUR. in 2010 till 5027.8 bln. RUR. in 2014 , or by $32 \%$

In 2014, one medium-sized enterprise employed, on the average, 121 people, small enterprise - 6 people, micro-enterprise employed 3 people (Table $3)$. In recent 4 years, 2011-2014, an average number of employees at micro- and small enterprises did not change, while an average medium business tended to employ fewer people. SME distribution across Russia is uneven. Most of the small and microenterprises are located in the Central Federal District and Volga Federal District, accordingly, $27.3 \%$ and $17,5 \%$ of all micro and small enterprises. North Western Federal District ranks 3rd, with the share of micro- and small enterprises equal to $15.8 \%$. Siberian Federal District ranks 4 th, with $14.4 \%$ of all micro- and small enterprises. In the other federal districts, the share of small and microenterprises does not exceed $10 \%$.

As for employment, the share of employment at micro- and small enterprises in Central Federal District exceeds by far the other districts. Specifically, the share of total employment in small and microenterprises in the Central Federal District is $30.6 \%$. The Volga Federal District ranks 2nd, with $21.4 \%$ of all employees engaged in small and microenterprises, while the Siberian Federal District ranks 3rd with $12.6 \%$ of all employees. The share of employees in the North Western Federal
District is slightly less, $11.8 \%$ of all employees.

Sales revenues of micro- and small enterprises in these districts are: $36.6 \%$ in the Central Federal District, $18.3 \%$ in the Volga Federal District and $10.7 \%$ in the Siberian Federal District.

Most of the medium businesses operate in the Central Federal District- 26.7\%, in the Volga Federal District $-21.4 \%$ and in the Siberian Federal District$14.6 \%$.

These districts demonstrate the largest indicators of employment and sales revenues for medium businesses, as well. The share of total employment in medium enterprises in the Central Federal District is $27.9 \%$, in the Volga Federal District$22.6 \%$, in the Siberian Federal District-13.5\%. The shares of sales revenues of all medium enterprises are $29.3 \%$ for the Central Federal District, $19.9 \%$ for the Volga Federal District and $13.1 \%$ for the Siberian Federal District.

\section{Structure of SME sector (legal entities).}

The structure of small and medium enterprises by sector in 2014 was mostly the same as before, with the largest share of enterprises engaged in trade and repair $-38.7 \%$ of all SMEs (legal entities). One fifth of all SMEs (legal entities) are engaged in real estate and services-20.3\%. The share of SMEs engaged in construction was $11.9 \%$, while the share of manufacturing SMEs in 2014 was 9.6\%.

As for the segment of medium-sized enterprises, the share of manufacturers is more significant, being $24.6 \%$, that is only slightly less than that of trade companies - 26.6\%. The share of medium companies engaged in agriculture, forestry and hunting in 2014 was $16.8 \%$.

Of interest are the data on financial performance of SMEs within 5 years. It is worthwhile looking at the ratio of profitable and loss-making companies. In 2014 the ratio-for micro-, small and medium businesses - was 80:20, that is, each 5th company was loss-making.

\section{CONCLUSIONS}

As we see, the development of Russian SMEs is considered to be challenging. And, based on the official indicators of SMEs development statistics, the government has made substantial progress in developing a complex program for the change of the mentality towards the market-driven. There is 
no doubt, it would be costly for Russia, and it would take much time and effort, but bring benefits in the long run.

Analyzing the current situation, we would state that there are some very light signals of the change of the economic policy in Russia towards increasing independence of the economy from the oil and gas prices on the international market, and more attention from the state to the SME sector development.

It should be noted, that Russia is entering the next stage of its economic development by gradually switching from "large corporations" economy to the growth through the SME sector.

The main objectives of the SMEs Development in Russia are:

- supporting SMEs and SME infrastructure forming companies;

- mobilizing funds from Russian, foreign and international institutions to support SMEs;

- providing information, marketing, financial, and legal support to investment projects implemented by SMEs;

- taking measures aimed to increase the share of purchases of SMEs' goods, works, and services by customers, defined by the Government of the Russian Federation, in the annual volume of purchases of goods, works and services, in the annual volume of purchases of innovative products, high-tech products;

- creating information exchange between SMEs and the state authorities, local authorities, and other bodies and organizations with an aim to support SMEs;

- Submitting proposals on improving support measures for SMEs, including proposals on legislative improvements regulating this field.

The Russian government is spending billions of rubles, providing support to SMEs throughout the country. The financial support is provided in two ways:

- General tax system with tax benefits and simplified system of taxation.

- The first one consists of specialized and basic incentives for SME:

- tax benefit to small enterprises for using accelerated depreciation methods;
- SMEs engaged in production of consumer goods, construction industry and several other fields, do not pay income tax in the first two years of operating.

The second way implies transition to the simplified system of taxation. Under this system certain companies are free to choose to pay single tax or federal, regional and local taxes (including VAT, property and sales taxes). Enterprises using this taxation system do not pay the uniform social tax, but they are obligated to pay pension insurance contributions, VAT on imported goods and state duties. Under these conditions taxpayers are entitled to choose whether they pay a uniform tax at a rate of $6 \%$ on the basis of all revenues or at a rate of $15 \%$ on the basis of income. In 2011, revenue from these special tax regimes, designed for SME, rose up to $15 \%$ and accounted 173.3 billion rubles. Tax reform, carried out in 2011, established new Patent-Based Simplified Taxation System. The Patent-Based STS might be used only by the sole entrepreneurs and allows performing business activity under the conditions of minimal tax burden and simplified reporting; the tax declaration is not required to be submitted, all payments are fixed and do not depend on the financial results of the entrepreneurship subject activity. In spite of the novelty of this tax system, experts note the significant rise of its popularity, revenue is announced to increase by two times.

To conclude, it is important to underline the great economy importance of SMEs for every country, as they perform multiple economic and social functions. In addition to tax deductions for budgets, SMEs develop economic sector by creating new workplaces and promoting market competition.

It is worth mentioning, that in the Russian Federation small and medium business is on the positive stage of growth, and it is engaged in the process of reaching the developed countries success. In spite of all drawbacks, the main aim has already been achieved. Russia's SME sector is increasingly gaining the attention of the Kremlin, and has been targeted by the State Duma and President V.V. Putin as a priority area for further development.

\section{REFERENCES}

Delmar, F., Davidsson, P., \& Gartner, W. B. (2003). 
Arriving at the high-growth firm. Journal of business venturing, 18(2), 189-216.

European Commission. Enterprise and Industry. Small and medium-sized enterprises (SMEs): SME Definition; Federal law №209-FZ "On small and medium business development in Russian Federation".

Eurostat data, NACE (Rev.2). Statistical Yearbook "Small and Medium Entrepreneurship in Russia 2015". Rosstat. - Moscow, 2015. - 96 p.

Eurostat data, NACE (Rev.2). Statistical Yearbook "Small and Medium Entrepreneurship in Russia 2015". Rosstat. - Moscow, 2015. - 98 p.

Federal Law Nr. 88 of 14 June 1995 "On State Support to Small Business in the Russian Federation

Federal Law of July 24, 2007 № 209-FZ “On the development of small and medium entrepreneurship in the Russian Federation

Kayser, G., \& Wallau, F. (2002). Industrial family businesses in Germany-Situation and future. Family Business Review, 15(2), 111-115.

Glancey, K., Greig, M., \& Pettigrew, M. (1998). Entrepreneurial dynamics in small business service firms. International Journal of Entrepreneurial Behavior \& Research, 4(3), 249-268.

Renzulli, L. A., Aldrich, H., \& Moody, J. (2000). Family matters: Gender, networks, and entrepreneurial outcomes. Social forces, 79(2), 523-546.

Russian Federal Tax, Statistic Data of Public and Government Registration https://www.nalog. ru/rn77/related_activities/statistics_and_anal ytics/regstats/

\section{ABOUT THE AUTHORS}

Emil Velinov, email: emil.velinov@vse.cz

Dr. Emil Velinov is an Assistant professor at the Department of Management at Faculty of Business Administration. He has completed his $\mathrm{PhD}$ studies at the latter institution in the area of International Management and Business. His international experience is related to managing interinstitutional projects in the area of Diversity Management, New Public Management and International Business. Dr. Velinov has been teaching in several universities across Europe including University of Economics and Business, Vienna, University of Liechtenstein, University of EconomicsPlekhanov, etc. He speaks fluently English, Czech, Bulgarian and Russian and he presents different research papers at international conferences in the area International Management, Diversity Management and Corporate Governance.

Dr. Maxim Ponomarev has been a Dean at the Management Faculty in Plekhanov Russian University of Economics, Moscow since 2013. He has graduated his $\mathrm{PhD}$ studies at State University of Voronez in Russia. He has published numerous papers in the area of Education Management, Organization Culture and Organization Development. At the same time his professional work involves a lot of inter-institutional research cooperation with European and Chinese universities and collaboration in developing methodology for executive education. Dr. Ponomarev has participated actively in domestic and international conferences in the area of Business and Economics and he speaks beside his native Russian, English as well. 
Attachments:

Table 1. SMEs classification in Russia

\begin{tabular}{|c|c|c|c|}
\hline SME type & Employment & Sales revenue & Share in registered capital \\
\hline Micro & $<15$ employees & $<60$ mln. RUR & \multirow{3}{*}{$\begin{array}{l}\text { Share of public bodies in the } \\
\text { registered capital is less than } \\
25 \% \text {, share of foreign legal } \\
\text { entities which are not SMEs is } \\
\text { less than } 49 \% \text {. }\end{array}$} \\
\hline Small & $\begin{array}{ll}16 \quad- & 100 \\
\text { employees }\end{array}$ & < 400 mln. RUR & \\
\hline Medium & $\begin{array}{lll}101 \quad- & 250 \\
\text { employees }\end{array}$ & $<1$ bln. RUR & \\
\hline
\end{tabular}

Source: Russian Federal Law, 2007

Table 2. Key SME performance indicators, as of January 1, 2015

\begin{tabular}{|l|c|c|c|c|c|}
\hline Type of SME & Micro & Small & Medium & $\begin{array}{c}\text { Individual } \\
\text { entrepreneurs }\end{array}$ & All SMEs \\
\hline $\begin{array}{l}\text { Number, } \\
\text { thousand }\end{array}$ & 1868.2 & 235.6 & 13.7 & 2413.8 & 4531.3 \\
\hline $\begin{array}{l}\text { Share in SME } \\
\text { sector, \% }\end{array}$ & 41.2 & 5.2 & 0.3 & 53.3 & $100 \%$ \\
\hline $\begin{array}{l}\text { Employment, } \\
\text { thousand } \\
\text { people }\end{array}$ & 4431.1 & 6358.4 & 1585.8 & 5645.7 & $18021^{*}$ \\
\hline $\begin{array}{l}\text { Sales } \\
\text { revenues, } \\
\text { bln. Rubles }\end{array}$ & 9699.3 & 16692.9 & 5027.8 & 10447.5 & 41867.5 \\
\hline
\end{tabular}

*SMEs account for 25\% of total employment. For reference: total employment in Russia as of end of 2014 is 71539 thousand people. Source: Labour and Employment in Russia. 2015. Statistical book. Rosstat, Moscow, 2015. p. 274

Source: Small and medium entrepreneurship in Russia. 2015. Rosstat. Moscow, 2015. p. 96 
Table 3. Key performance indicators of SMEs (legal entities), 2010-2014.

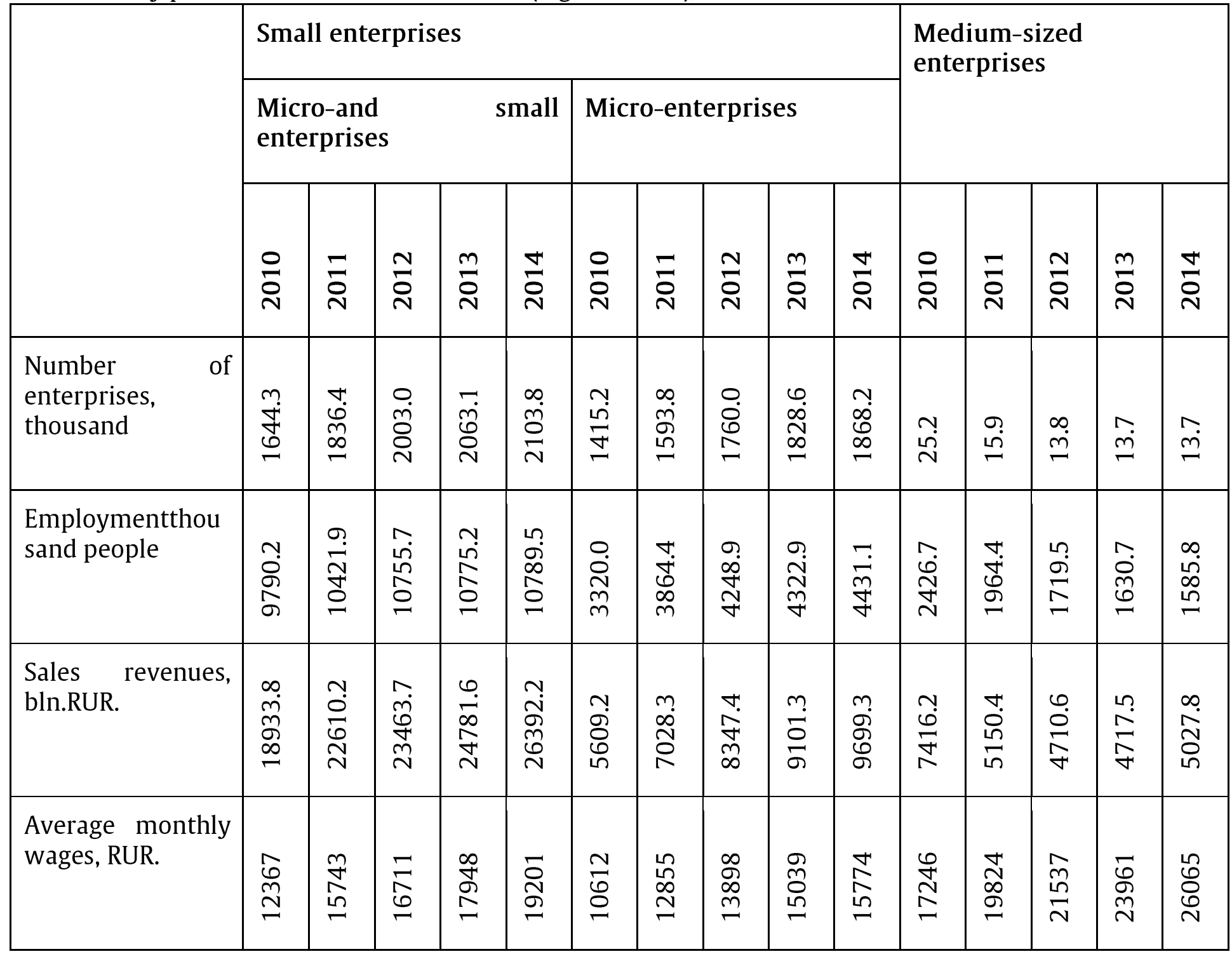

Source: Statistical Yearbook "Small and Medium Entrepreneurship in Russia 2015". Rosstat. - Moscow, 2015, p. 96 
Table 5. Financial performance: Profit \& Lost of SMEs (accounting and reporting data), 2010-2014.

\begin{tabular}{|c|c|c|c|c|c|}
\hline & \multirow{3}{*}{$\begin{array}{l}\text { Number of } \\
\text { enterprises }\end{array}$} & \multicolumn{4}{|l|}{ Including } \\
\hline & & \multicolumn{2}{|l|}{ Profitable SMEs } & \multicolumn{2}{|c|}{ Loss-making SMEs } \\
\hline & & $\begin{array}{l}\text { Number } \\
\text { enterprises }\end{array}$ & $\begin{array}{l}\text { Total profit, } \\
\text { mln. RUR }\end{array}$ & $\begin{array}{l}\text { Number of } \\
\text { enterprises }\end{array}$ & $\begin{array}{l}\text { Total loss, } \\
\text { mln. RUR }\end{array}$ \\
\hline \multicolumn{6}{|c|}{ Microenterprises } \\
\hline 2010 & 435119 & 347183 & 457694 & 87936 & 216676 \\
\hline 2011 & 406206 & 331200 & 369548 & 75006 & 170479 \\
\hline 2012 & 500314 & 412360 & 715371 & 87954 & 177090 \\
\hline 2013 & 1155668 & 931644 & 1297496 & 224024 & 447613 \\
\hline 2014 & 1328352 & 1061436 & 1648981 & 266916 & 749455 \\
\hline \multicolumn{6}{|c|}{ Small and microenterprises } \\
\hline 2010 & 525399 & 416778 & 868401 & 108621 & 332407 \\
\hline 2011 & 495484 & 402641 & 776796 & 92843 & 302628 \\
\hline 2012 & 602698 & 496030 & 1256205 & 106668 & 305994 \\
\hline 2013 & 1344849 & 1082082 & 2093226 & 262767 & 656174 \\
\hline 2014 & 1530294 & 1219954 & 2548634 & 310340 & 1337684 \\
\hline \multicolumn{6}{|c|}{ Medium enterprises } \\
\hline 2010 & 15190 & 11658 & 209699 & 3532 & 70312 \\
\hline 2011 & 14746 & 11727 & 233521 & 3019 & 71420 \\
\hline 2012 & 16499 & 13571 & 296286 & 2928 & 80009 \\
\hline 2013 & 17411 & 14126 & 308519 & 3285 & 108360 \\
\hline 2014 & 18747 & 14937 & 334392 & 3810 & 191257 \\
\hline
\end{tabular}

Source: Statistical Yearbook "Small and Medium Entrepreneurship in Russia 2015". Rosstat. Moscow, 2015. p. 96 